\title{
Romulus and Peter: Remembering and Reconfiguring Rome's Foundation in Late Antiquity
}

\author{
Mark Humphries
}

1 Introduction: the Celebration That Never Was

On 21 April 348, nothing happened. ${ }^{1}$ This is an exaggeration, of course: surely something must have happened somewhere on that date. Rather, on 21 April 348 something significant and apparently long-expected did not happen. This was so unusual that it called for detailed comment in the epitome of Roman imperial history written a decade or so later by Sextus Aurelius Victor. In the course of his account of the emperor Philip the Arab (244-249), Victor observed that the millennium of Rome's foundation on 21 April 248 had been the occasion for a visit by the emperor and his son, who engaged in acts of architectural patronage and hosted grand celebrations to mark this important milestone. ${ }^{2}$ How striking, therefore, was the omission of any similar celebrations a century later for the 110oth anniversary of the city's foundation. ${ }^{3}$ Indeed, Victor felt he could discern a pattern in history. First, the events (or non-events) of 348 happened in the time of another Philip, one of the consuls of that year. ${ }^{4}$ Furthermore, Victor reports prodigies and portents observed before the millennium in 248 ,

1 I am grateful to the symposium organisers for their invitation and subsequent help, as well as to the audience at the colloquium for their contributions. Roald Dijkstra deserves special thanks for his editorial advice (and saintly patience). The discussion of Prudentius owes much to the discussion of his Peristephanon at the reading group of KYKNOS: The Research Centre for Ancient Narrative Literature at Swansea University. The references below could be expanded hugely, given the current bibliography on the subject; I have opted, therefore, to cite mainly recent works, in which references to older studies may be chased up. Omission here involves no value judgement.

2 Aur. Vict., Caes. 28.1: Igitur Marcus Iulius Philippus Arabs Thraconites, sumpto in consortium Philippe filio, rebus ad Orientem compositis conditoque apud Arabiam Philippopoli oppido Romam venere; exstructoque trans Tiberim lacu, quod eam partem aquae penuria fatigabat, annum urbis millesimum ludis omnium generum celebrant.

3 The closest the reigning western emperor, Constans, got to Rome in 348, it seems, was Milan on 17 June: CTh 10.14.2.

4 Fl. Philippus, praetorian prefect of Oriens: Bagnall, Cameron, Schwartz, \& Worp (1987) 230-1.

(C) MARK HUMPHRIES, 2020 | DOI:10.1163/9789004425682_010

This is an open access chapter distributed under the terms of the CC BY-NC 4.0 license, Humphries - 9789004425682 
including the appearance of female genitals on a slaughtered pig, that clearly pointed to 'the decadence of later generations and the aggravation of vices'.

For Aurelius Victor, then, one of the markers of his age was that Rome was, through this act of non-commemoration, seemingly cut adrift from the traditional story of its origins. There is reason to suppose, however, that in spite of his complaint, the foundation of Rome continued to be celebrated in the city in the fourth century. The list of festivals contained in the Chronograph of 354 - so dating to just six years after the omission about which Aurelius Victor complains - clearly lists the natalis Urbis on 21 April. ${ }^{6}$ Meanwhile the existence of the preserved hut of Romulus (casa Romuli) on the Palatine hill is noted in the fourth century regionary catalogues, and in dismissive remarks by Jerome and Ambrose of Milan. ${ }^{7}$ And at the beginning of the century, the emperor Maxentius (306-12) had advertised his devotion to Roman traditions by showing the twins and the wolf on his coins, and by naming his son Romulus. ${ }^{8}$

Yet even if memory of Rome's foundation by Romulus was still preserved, the fourth century was a period in which a very different story of Rome's foundation, as an apostolic see established by Peter, was beginning to achieve currency. If, instead of looking back a century from 348 to the time of Philip the Arab we look forward another hundred years to the time of Valentinian III (425-455), we have a very emphatic statement of that origins story in a famous law issued by the emperor in July 445 that sought to shore up the authority of Pope Leo at Rome in opposition to the overreaching metropolitan claims being made in the Gallic Church by bishop Hilary of Arles. ${ }^{9}$ Valentinian (or, rather, the quaestor who composed the law on his behalf) began by invoking God's protection for himself and for the empire. He then stated his support for papal supremacy, prefacing it with a statement of the three props of Roman authority, against which there should be no opposition: 'the primary merit of

5 Aur. Vict., Caes. 28.2: Et quoniam nomen admonuit, mea quoque aetate post mille centesimus consule Philippo excessit nullis, ut solet, sollemnibus frequentatus: adeo in dies cura minima Romanae urbis. Quod equidem denuntiatum ferunt illo tempore prodigiis portentisque; ex quis unum memorare brevi libet. Nam cum pontificum lege hostiae mactarentur, suis utero maris feminarum genitalia apparuere. Id haruspices solutionem posterorum portendere vitiaque fore potiora interpretati.

6 Fasti Philocali, ed. Mommsen (1893) 262. The festival is preserved also in the calendar of Polemius Silvius a century later: ibid., p. 263.

7 Curiosum Urbis Rome and Notitia Urbis Romae, ed. Jordan (1871) 557; Jerome, Prologus in Didymi libro de Spiritu sancto: Illico ego uelut postliminio Hierosolymam sum reuersus et, post Romuli casam et ludicrum Lupercal, diuersorium Mariae et speluncam Saluatoris aspexi. Ambrose, Ep. 73.32: pastorales casas auro degeneri renitentes.

8 Cullhed (1994) 47-9.

9 Nov. Val. 17 (8 July 445). 
the apostolic see of St Peter, who is the first of the apostolic crown; the dignity of the city of Rome; and the authority of a sacred synod.'10

These views echo a reappraisal of Rome's founding that had been voiced by Leo himself in sermons delivered on the feast of Peter and Paul on 29 June early in the 440s. In 441, for example, he had remarked of the apostles:

These are your holy Fathers and true shepherds, who gave you claims to be numbered among the heavenly kingdoms, and built you under much better and happier auspices than they, by whose zeal the first foundations of your walls were laid: and of whom the one that gave you your name defiled you with his brother's blood. ${ }^{11}$

This statement makes it abundantly clear that Leo has in mind Peter and Paul as (re)founders of a specifically Christian Rome. Moreover, it explicitly opposes them to Rome's mythic founders, Romulus and Remus: the latter had been inferior shepherds when compared with the apostles, and their foundation act was stained by fratricidal violence.

Here, as in so many things, Leo was developing a tradition, not inventing one ex nihilo. ${ }^{12}$ It is likely significant that in articulating an alternative version of Rome's foundation, he is appealing to stories that resembled each other (twin founders) and that had a long history (commemoration of Peter and Paul at Rome predates Leo's assertions by at least two centuries); in other words, he is 'anchoring' his innovation in a firmly established tradition. ${ }^{13}$ Even so, the striking opposition of Peter and Paul to Romulus and Remus warrants further exploration. In this paper, I will tackle the issue as follows. First, I will review the foundation of Rome and its commemoration as it was articulated in the fourth and early-fifth centuries. This will show that there was no single, agreed narrative, and, furthermore, that the associations with fratricide were already regarded as problematic. Secondly, I want to look in rather more detail at some instances of how this foundation story was rewritten in the years around 400

$10 \quad$ Nov. Val. 17 pr.: sedis apostolicae primatum sancti Petri meritum, qui princeps est episcopalis coronae, et Romanae dignitas civitatis, sacrae etiam synodifirmasset auctoritas.

11 Leo, Tract. 82.1: isti sunt sancti patres tui verique pastores, qui te regnis coelestibus inserendam multo melius multoque felicius condiderunt, quam illi quorum studio prima moenium tuorum fundamenta locata sunt: ex quibus is qui tibi nomen dedit fraterna te caede foedavit. For earlier developments, Huskinson (1982) remains a classic study; see now also Demacopoulos (2013) 13-38. For the importance of martyr cult to the emerging papacy, see most recently Trout (2015) 1-47. For the importance of Peter and Paul in the context of relationships between bishop, emperor, and senate, see now Thacker (2012).

Demacopoulos (2013) 44, 49 . 
by looking at the Spanish poet Prudentius, who on a number of occasions juxtaposes myths of early Rome with explicit statements that this had been superseded by a new Christian foundation and dispensation. By such means, I aim to shed some light on the process by which late antiquity saw a recasting of Rome's foundations, in which Romulus and Remus were replaced by Peter and Paul.

\section{Romulus in Late Antiquity: Contested Traditions and Commemorations}

The Liber de Caesaribus of Aurelius Victor with which I began is one of a number of abbreviated histories surviving from the late antique period. While Victor began his narrative with the accession of Augustus, others, such as Eutropius and Festus, both writing in the reign of Valens $(364-378)$ went further back, to Rome's earliest days. Of these, Festus' work is extraordinarily abbreviated, and its account of Rome's foundation does little more than note that Romulus came first and ruled for 37 years. ${ }^{14}$

Rather more detail can be found in Eutropius' slightly earlier Breviarium. His version reads:

The Roman Empire (than which human memory can recall scarcely any smaller in origin or greater in its growth throughout the whole world) derives its origin from Romulus, the son of Rhea Silvia, a Vestal Virgin, and, as was believed, of Mars. He was brought forth in one birth with his brother Remus. While leading the life of a robber among the shepherds, at the age of eighteen he founded a small city on the Palatine Hill on the eleventh day before the Kalends of May [21 April], in the third year of the sixth Olympiad, in the three hundred and ninety-fourth year after the destruction of Troy, according to those who give the earliest and latest dates. ${ }^{15}$

\footnotetext{
14 Festus, Brev. 2: Romulus regnauit annos XXXVII.

15 Eutropius, Brev. 1.1: Romanum imperium, quo neque ab exordio ullum fere minus neque incrementis toto orbe amplius humana potest memoria recordari, a Romulo exordium habet, qui Reae Silviae, Vestalis virginis, filius et, quantum putatus est, Martis cum Remo fratre uno partu editus est. Is cum inter pastores latrocinaretur, decem et octo annos natus urbem exiguam in Palatino monte constituit XI Kal. Maias, Olympiadis sextae anno tertio, post Troiae excidium, ut qui plurimum minimumque tradunt, anno trecentesimo nonagesimo quarto.
} 
The next chapter adds, after an account of Rome's earliest territorial expansion (including the rape of the Sabine women), an account of Romulus' death (or, rather, disappearance) and deification, followed by an interregnum by the senators (this last detail is also found in Festus). Eutropius' account essentially summarises earlier traditions, ${ }^{16}$ such as those found in Livy, but it is striking not just for what it includes, but also for what it omits. There is no mention at all of the death of Remus, and the accusation of fratricide against Romulus, that would be such a feature of Leo's sermonising about the superiority of Peter and Paul over the twins. In fact, Remus just quietly disappears from the narrative.

But this is only one of several versions of the Romulus and Remus story that was circulating in the fourth century. A brief consideration of some others will show something of their variety, as well as the ways in which they dealt with the difficulty presented by the fratricide. The so-called Chronicon Urbis Romae preserved in some manuscripts of the Chronograph of 354, and likely a work of the first half of the fourth century, reports that the Remus killed by Romulus was the last king of Alba Longa. ${ }^{17}$ At the other end of the fourth century, another variant, which similarly side-steps the issue of fratricide, is found even in the Christian Jerome's Latin version of Eusebius' Chronological Canons: having noted the foundation of Rome on the Palilia (21 April: sometimes found as Parilia) and adding that the day is still kept as a festival, it states that Remus was killed not by Romulus but by Fabius. ${ }^{18}$ Another text probably from the second half of the fourth century, the anonymous Origo Gentis Romanae, seems to reflect a certain anxiety about the fratricide narrative. After its account of the rivalry of Romulus and Remus it remarks:

In truth, Licinius Macer in Book I instructs us that there was a baleful outcome of that dispute, for indeed Remus and Faustulus, abiding in that very place, were killed. In contrast, Egnatius in Book I relates that not only was Remus not killed in the dispute but also that he lived longer than Romulus. ${ }^{19}$

16 On the repetitiveness of these traditions about early Rome, see Smith (2011) 23-4.

17 Ed. Mommsen (1892) 143-4. On the name and date of the work, see Burgess (2012) 351. For discussion of its complex historiography, see Salzman (1990) 52-6.

18 Jerome, Chron. ed. Helm, 152: Roma Palilibus, qui nunc dies festus est, condita. Remus rutro pastorali a Fabio Romuli duce occisus.

19 Origo Gentis Romanae 23.5-6: At vero Licinius Macer libro primo docet contentionis illius perniciosum exitiam fuisse; namque ibidem obsistentes Remum et Faustulum interfectos. Contra Egnatius libro primo in ea contentione non modo Remum non esse occisum sed etiam ulterius a Romulo vixisse tradit. Discussion in Momigliano (1958) 68. 
Such anxiety about the death of Remus was by no means new, and had been apparent, for instance, in literature of the late Republic and the age of Augustus..$^{20}$ Clearly, the fourth century saw no diminution in these concerns.

If accounts of the 'historical' Romulus and Remus present us with an array of different versions of their story, reflections on their commemoration are no more straightforward. As noted above, Aurelius Victor's account of Philip the Arab's commemoration of Rome's millennium carried with it an expression of regret that the eleventh centenary was not celebrated in like fashion, and that this portended Roman decadence. By contrast, Eutropius' account of the commemoration of Rome's millennium, while noting its magnificence, makes no such nod forwards to the failure of fourth century emperors to observe the later centenary. ${ }^{21}$ However, there is another author who does provide a more contentious account of the celebration of Rome's millennium and of its significance, and plainly does so from religious scruple.

Writing towards the end of the decade following Alaric's sack of Rome in 410, the Spaniard Paulus Orosius, in his Seven Books of Histories against the Pagans, gives a famously tendentious account of human history and the Christian God's role within it as part of an apologetic narrative that defended Christians from accusations that it was their abandonment of Rome's ancestral religions that had led to the fall of the city into Gothic hands. ${ }^{22}$ His account of the celebrations in 248 must rank among the more spectacular of his fictions:

997 years after the foundation of the City, Philip was made the 23rd emperor after Augustus. He made his son, Philip, his co ruler and reigned for seven years. He was the first of all the emperors to be a Christian, and after two years of his rule the 10ooth year after the foundation of Rome was completed. So it came to pass that this most preeminent of all her previous birthdays was celebrated with magnificent games by a Christian emperor. There can be no doubt that Philip dedicated the gratitude and honour expressed in this great thanksgiving to Christ and the church, as no author speaks of him going up to the Capitol and sacrificing victims there as was the custom. Nevertheless, the two Philips died in a mutiny and through Decius's treachery, though in different places. ${ }^{23}$

\footnotetext{
20 Wiseman (1995) 143-50.

21 Eutrop., Brev. 9.3. His imperantibus millesimus annus Romae urbis ingenti ludorum apparatu spectaculorumque celebratus est.

22 Van Nuffelen (2012).

23 Orosius, 7.20.1-4: Anno ab urbe condita DCCCCLXLVII Philippus uicensimus quartus ab Augusto imperator creatus Philippum filium suum consortem regni fecit mansitque in eo annis septem. Hic primus imperatorum omnium Christianus fuit ac post tertium imperii
} 
The tradition that Philip was a Christian was by no means new, and is found in other works, such as Eusebius' Ecclesiastical History, but there is no mention there that it had any impact on the celebration of Rome's millennium. ${ }^{24}$ This seems to be wholly Orosius' unique extrapolation from the sources at his disposal. In that respect, it equals his remarkable assertion that Jesus was born at the time of a Roman census so that he could be enrolled as a Roman citizen. ${ }^{25}$

Orosius goes to some lengths to present an idealised depiction of Philip and his son. There is no mention whatsoever that Philip the elder came to the throne through the murder of Gordian III, a feature mentioned by Aurelius Victor; nor is there any mention of the Philips' deification, as mentioned by Eutropius. ${ }^{26}$ In short, Philip and his son are depicted in such a way as to remove any stain of impiety from them. Indeed, they are themselves presented as victims of their wholly pernicious pagan successor Decius, who, as a final act of vengeance against them, initiated a purge of the Christians they had favoured. ${ }^{27}$ Thus, Orosius' account of Rome's millennium represents a carefully crafted Christian version of it, which suited his wider argument that the Roman empire had been decreed as an instrument of God's will in human history.

Moreover, this description of the millennial celebrations can be linked to Orosius' account of Rome's foundation, which makes clear the nature of the pollution that Philip's Christian commemoration needed to expunge:

The city of Rome in Italy was founded by the twins Romulus and Remus. Romulus at once ruined the reputation of his reign by murdering his brother and immediately followed this crime by another of equal cruelty. He gave as a dowry to the Sabine women, who had been seized and bound in shameless wedlock to the Romans, the blood of their husbands and parents. After killing first his grandfather Numitor and next his brother Remus, Romulus seized the sovereign power and founded the city. With blood he dedicated the kingdom of his grandfather, the walls of

eius annum millesimus a conditione Romae annus impletus est. Ita magnificis ludis augustissimus omnium praeteritorum hic natalis annus a Christiano imperatore celebratus est. Nec dubium est, quin Philippus huius tantae deuotionis gratiam et honorem ad Christum et Ecclesiam reportarit, quando uel ascensum fuisse in Capitolium immolatasque ex more hostias nullus auctor ostendit. Ambo tamen quamuis diuersis locis tumultu militari et Decii fraude interfecti sunt.

24 Eus., $H E$ 6.34.

25 Orosius 6.22.6-8; 7.3.4.

26 Aur. Vict., Caes. 27; Eutrop., Brev. 9.3.

27 Orosius, 7.21.2. The story derives from Eusebius, $H E$ 6.39.1. 
his brother, and the temple of his father-in-law; and he assembled a band of criminals by promising them exemption from punishment. His first battlefield was the Forum of the City, a fact signifying that foreign and civil wars, always interrelated, would never cease. ${ }^{28}$

It is quite clear that here we are dealing with the sort of negative appraisal of Romulus and Remus to which Leo was appealing a few decades later when he compared Rome's founding twins so unfavourably with the apostles Peter and Paul.

From both secular and avowedly Christian perspectives, then, the story of Romulus was a topic for debate in the fourth and fifth centuries. It is tempting to wonder if the misgivings expressed by secular sources somehow echo the ripples of Christian polemic about the story; the available sources make this difficult to demonstrate with certainty, and, in any case, we have seen that disquiet about Romulus' crime can be found already in the late Republic. Even so, the Christian interventions on the debate perhaps reflect wider concerns to criticise aspects of the maintenance of age old traditions as part of Rome's heritage, a strategy visible at the end of the fifth century in the attack mounted by Pope Gelasius I (492-496) on the continued celebration of the Lupercalia. ${ }^{29}$

\section{From Romulus and Remus to Peter and Paul in the Poetry of Prudentius}

In the same year that no emperor celebrated Rome's eleventh centenary, 348, the Spanish poet Aurelius Prudentius Clemens was born..$^{30}$ Like others of his countrymen, he found favour with the Spanish emperor Theodosius I, which brought him to Rome, where he was able to visit the shrines of the martyrs. ${ }^{31}$ Towards the end of his life, he edited his various poems for publication, furnishing them with a preface that gives details of the year of his birth, of his

28 Orosius 2.4.1-4: Urbs Roma in Italia a Romulo et Remo geminis auctoribus condita est. Cuius regnum continuo Romulus parricidio imbuit, parique successu crudelitatis sine more raptas Sabinas, inprobis nuptiis confoederatas maritorum et parentum cruore dotauit. Itaque Romulus, interfecto primum auo Numitore dehinc Remo fratre, arripuit imperium urbemque constituit; regnum aui, muros fratris, templum soceri sanguine dedicauit; sceleratorum manum promissa inpunitate collegit. Primus illi campus ad bellum forum urbis fuit, mixta simul externa ciuiliaque bella numquam defutura significans.

29 McLynn (2008) esp. 172-5 on the importance of such rituals to the city's 'heritage industry'.

$30 \quad$ Prudentius, Praef. 24: Saliae consulis.

$31 \quad$ Harries (1984) 69-73. 
education, and of his political career. Now, contemplating his mortality, he asked that his sinning soul shed its frivolous ways, and that his voice should honour God, fight heresy, expound the Catholic faith; he also encouraged Rome to follow this lead:

Trample on the rites of the heathen, strike down your idols, O Rome, and devote song to the martyrs and praise the apostles. ${ }^{32}$

As is well known, a number of Prudentius' poems offer meditations on Rome's history, ${ }^{33}$ and in this section I want to suggest ways in which they elaborate on this theme and offer reflections on the role of the apostles Peter and Paul in, effectively, a re-foundation of Rome that is superior to that of Romulus and Remus. I will concentrate on his two most overtly political works, the Peristephanon Liber, a collection of hymns on martyr cult which, even if it focuses on cults from his native Spain, also provides a number of accounts of Roman martyrs, including Peter and Paul; and secondly, the two books of anti-pagan verse polemic Contra Symmachum, a refutation of the arguments of the pagan senator Q. Aurelius Symmachus, which highlights the superiority of Peter and Paul in a Christian reconfiguration of Roman history. ${ }^{34}$

Prudentius' Peristephanon comprises a collection of hymns on various martyrs, many of whom came from Spain, particularly Calahorra (Calagurris) and Zaragossa (Caesaraugusta), likely candidate for Prudentius' patria. ${ }^{35}$ Yet amid this account of Spanish martyrs are scattered some of witnesses to the faith from other parts of the Roman world, and chief amongst those are a number of saints from Rome itself. These include the redoubtable virgin Agnes (Perist. 14), Hippolytus (Perist. 11), and, perhaps most famous, Laurentius, who goads his tormentors, who are roasting him on a gridiron, to taste his seared flesh to check if he is cooked or not (Perist. 2.401-8); significantly, there is a twin narrative of the martyrdom of Peter and Paul (Perist. 12). Many of these hymns present their tales in a fashion that represents a refashioning of Roman history and identity, a process that is neatly summed up by the opening line of the poem on Agnes which remarks that 'The sepulchre of Agnes is in the home

32 Prudentius, Praef. 40-2. Translations are taken, sometimes with emendation, from Thomson (1949-1953).

33 See Gnilka (2012) for Prudentius' understanding of Roman constitutional history (highlighting problems arising from the transmission of his text).

34 For the possibility that the two books were written separately and then combined into one work, see Harries (1984) 73-80. 
of Romulus. ${ }^{36}$ Evocations of Rome's distant, ancient past are found also in the hymn to Hippolytus, where pagan Rome is described in terms of its foundation from Troy. ${ }^{37}$

In Prudentius' view, however, these ancient identities are to be wiped clean with the advent of Christianity. The hymn to Lawrence provides some striking examples. It opens with a clear statement of this theme: 'Ancient mother of temples, already Rome is dedicated to Christ; victory and the triumph over barbarian rites through Lawrence's leadership.' ${ }^{38}$ The text goes on to remark that the blood spilled in Lawrence's martyrdom is superior to that shed in any Roman conquest, making Rome's greatness a specifically Christian achievement. There is an implicit link too with the extinction of blood sacrifice at Rome: following Lawrence's martyrdom, the statues of the ancient gods, washed clean of their sacrificial stains, will shine forth as harmless images (aera innoxia). ${ }^{39}$ This recalibration of Rome's history is pursued in the famous exchange between Lawrence and his tormentors, in which the city's greatness is presented as a consequence of God's plan for humankind. Lawrence, on the gridiron, prays for mercy for the 'city of Romulus', and remarks that:

The Father, creator of earth and sky and founder of this city [auctor horum moenium ], ... has set the sceptre of the world on Rome's high citadel, ordaining that the world obey the toga of Quirinus and yield to his arms, that you might bring under one system of laws the customs and observance, the speech and the character and worship of nations which differed among themselves; lo, the whole race of men has passed under the sovereignty of Remus, and usages formerly discordant are now alike in speech and thought. This was appointed so that the authority of the Christian name might bind with one tie all the lands everywhere. ${ }^{40}$

This rewriting of Rome's destiny in Christian guise also looms large in the two books Prudentius wrote as a condemnation of pagan cult in his Contra

$36 \quad$ Perist. 14.1: Agnes sepulchrum est Romulea in domo.

37 Perist.11.6: cum coleret patrios Troia Roma deos.

38 Perist. 2.1-4: Antiqua fanorum parens, / iam Roma Christo dedita, / Laurentio uictrix duce / ritum triumfas barbarum.

39 Perist. 2.481-484, with commentary and parallels in O'Hogan (2016) 140-4.

40 Perist. 2.416-432: auctor horum moenium, / qui sceptra Romae in uertice / rerum locasti, sanciens / mundum Quirinali togae / seruire et armis cedere, / ut discrepantum gentium / mores et obseruantiam / linguasque et ingenia et sacra / unis domares legibus! / En omne sub regnum Remi / mortale concessit genus, / idem loquuntur dissoni / ritus, id ipsum sentiunt. / Hoc destinatum, quo magis / ius christiani nominis, / quodcumque terrarum iacet, / uno inligaret uinculo. 
Symmachum. The idea that Rome's destiny had been decreed by God is repeated in terms very similar to those found in the Peristephanon:

God, wishing to bring into partnership peoples of different speech and realms of discordant manners (discordes linguis populos et dissona cultu), determined that all the civilized world should be harnessed to one ruling power and bear gentle bonds in harmony under the yoke, so that love of their religion should hold men's hearts in union. ${ }^{41}$

In both works, Rome's destiny to world empire, and its civilising mission concepts familiar to any reader of Virgil or the Elder Pliny - are emphatically Christianized. ${ }^{42}$

Just as Prudentius makes Lawrence ascribe the pre-eminence of 'the toga of Quirinus' and the 'sovereignty of Remus' to the work of the Christian God, so too Rome itself was set under the tutelage of an alternative pair of founders, Peter and Paul. In the hymn to Hippolytus they are pre-eminent as safeguards against error and guarantors of unity:

Let the faith be strong in its unity, the faith that was established at the very outset of the church, and which Paul, alongside the chair of Peter, holds fast. ${ }^{43}$

By the time Prudentius was writing, in the 39os, Rome was home to two great basilicas of the apostles, as the early church of St Peter's on the Vatican was joined by Theodosius' dedication of St Paul's on the Via Ostiensis. ${ }^{44}$ The hymn in the Peristephanon to the apostles makes clear references to these churches, ${ }^{45}$ while also noting the emerging precedence of Peter over Paul: Peter was martyred a year to the day before Paul, while on the feast of the saints, in which the plebs Romula is fully involved, attention is devoted first to Peter, and then to Paul. ${ }^{46}$

$41 \quad$ C. Symm. 2.586-91.

42 See esp. Perist. 2.421-4 (ut discrepantum gentium / mores et obseruantiam / linguasque et ingenia et sacra / unis domares legibus) and C. Symm. 2.586 (discordes linguis populos et dissona cultu). For Prudentius' ideological transposition of the climax of the praeparatio evangelica from the Constantinian to the Theodosian age, see Gnilka (2015) 171-5.

Perist. 11.31-2: Vna fides uigeat, prisco quae condita templo est, / quam Paulus retinet quamque cathedra Petri.

44 For the church, and its relation to Prudentius' verse, see Liverani (2012). For the importance of Peter and Paul to the Theodosian dynasty, see Lønstrup Dal Santo (2015) 106-9.

45 Discussion in O'Hogan (2016) 160-4.

46 Perist. $12.21-4$ and $55^{-66 .}$ 
This association of Christian Rome with its apostolic (re)founders is explicit also in the Contra Symmachum. Even if the two books were written separately, in the form in which they were edited for publication by Prudentius himself, they were furnished with prefatory hymns to the apostles. The first book's preface deals with Paul, and contains a further evocation of the image of Rome's imperial expansion in Christian guise, but this time the subjugation of the barbarians to Roman rule is recast as submission by the Romans themselves to Paul's preaching:

Paul, the herald of God, who first with his holy pen subdued the wild hearts of the Gentiles and with his peaceable teaching propagated the knowledge of Christ over barbarous nations that followed savage ways, so that the untamed pagan race might come to know God and reject its own rituals. ${ }^{47}$

Just as Paul came to Rome after enduring a storm, so Rome, after the tempests of paganism, would come to redemption through Christ, a process in which Paul acted as 'saviour of the race of Romulus.'48 Similar imagery is evoked in the preface to book 2, which focuses on Peter and the storm on the sea of Galilee, where the apostle's faith was tested, and nearly faltered, until he expressed true faith in Christ. In that respect, Peter's experience can be seen as standing for the populus Romanus, whose faltering before the Christian gospel echoed Peter's uncertainty, and who had had their faith tested by a tempest, in this case the storm of Symmachus' eloquence. ${ }^{49}$ Moreover, as the second book of the Contra Symmachum progresses, it stresses that it is faith in Christ that endures and points the way to the future, and that Rome's earlier religious history, from the time of Romulus, was inconstant and shifting, not least because gods allowed peoples who had worshipped them previously to be conquered by Rome. ${ }^{50}$ The era of Romulus is held up as an example of the absurdity of those who demand that Rome hold fast to the traditions of its ancestors. ${ }^{51}$ As Prudentius observes, this would require, amongst other things, a return to a foraging, pre-agricultural lifestyle, or a decision to reside once more in flimsy

47 C. Symm., praef. 1.1-6: Paulus, praeco Dei, qui fera gentium / primus corda sacro perdomuit stilo, / Christum per populos ritibus asperis / inmanes placido dogmate seminans, / inmansueta suas ut cerimonias / gens pagana Deo sperneret agnito; see O'Hogan (2016) 76 for the imperial echoes.

48 C. Symm. praef. 1.80: Salvator generis Romulei.

49 C. Symm. praef. $2.5^{6-8 .}$

$50 \quad$ C. Symm. $2.488-577$.

$5^{1} \quad$ C. Symm. 2.277-8: quidquid rudibus mundi nascentis in annis mos habuit. 
huts of the type used by Romulus and Remus themselves. ${ }^{52}$ On the contrary, Rome's history since the days of Romulus had been one of constant change. ${ }^{53}$ Only through faith in Jesus Christ, could Rome realise its true destiny, an idea that Prudentius articulates through a speech delivered by Roma herself: here she extolls the recent victories won under Christian standards, which make her vow to shut the temples, end sacrifices, and 'no longer permit evil spirits know the citadels of Romulus' (ne quis Romuleas daemon iam noverit arces); instead, allegiance should be paid alone to God and Christ. ${ }^{54}$

\section{4}

\section{Conclusions}

The poems of Prudentius reflect a decisive shift in the perception of Rome's origins, in which the primordial foundation under Romulus (and Remus) was effaced by a new narrative that prioritised Peter (and Paul). We have seen that already by the fourth century, the story of Romulus and Remus presented Roman authors with a problematic vision of the city's origins, in which the foundational act was stained with the blood of fratricide. This was a difficulty that authors sought to confront by various means, ranging from passing over it in silence (as Eutropius did) to denying it outright (as, for example, in the Origo Gentis Romanae's quotation of Licinius Macer). How any of this relates to the non-commemoration of 348 is difficult to judge, but by the early fifth century, Orosius' account of Rome's origins, when read in the light of his narrative of Philip the Arab's Christian celebration of Rome's millennium, suggests that for some Christians a rejection of the foundation tale by Romulus and Remus was desirable.

That rejection is plain by the time of Leo the Great, as is the anchoring of Rome's foundation narrative in another story, that of Peter and Paul. That this was already developing by $c .400$ is clear from the significant echoes of this new foundational narrative, and its explicit opposition to the version with Romulus and Remus, in the poetry of Prudentius. His testimony is particularly valuable because, by virtue of the poet's Spanish origins, it represents the views of an outsider. Yet his recalibration of Rome's origins was no misinterpretation of a viewer from the outside: this is demonstrated by topographic changes between the mid-fourth and mid-fifth centuries that echo the vision found in Prudentius. These are signalled most strongly by the engagement of emperors

\footnotetext{
52 C. Symm. 2.282-302.

53 C. Symm. 2.303-8.

54 C. Symm. 2.709-68.
} 
with the city of Rome, and they point to the increasing importance of Peter in particular, and especially his tomb and basilica on the Vatican, in such interactions. In 403-4 and again in 407-8 - and therefore within a decade of Prudentius' praises of Rome's apostolic foundation - the emperor Honorius (395-423) visited Rome, and during these sojourns went to the Vatican basilica. ${ }^{55}$ Honorius' first visit to Peter's shrine seems to have been made as a thank-offering above all for the repulsion of Alaric's Goths from Italy, and in a gesture of gratitude to the apostle, the emperor deposited his diadem on the basilica's altar. ${ }^{56}$ Later in the century, the many Roman visits of Valentinian III (425-55) saw imperial participation in the liturgy at the Vatican. ${ }^{57}$ The rising profile of St Peter's in ceremonial terms reflected the church's increasing importance as a locus of imperial display: under Honorius, an imperial mausoleum was erected beside St Peter's, associating the church very firmly with the Theodosian dynasty in the west, several of whom were buried there. ${ }^{58}$ Also in the first half of the fifth century - either under Honorius or, perhaps more likely, under Valentinian III - a new imperial residence seems to have been constructed on the Colle Pincio overlooking the Campus Martius, and on a sightline with St Peter's across the river. ${ }^{59}$ Such ceremonial and spatial shifts towards the Vatican complex suggest that if Romulus and his foundation of the city were indeed becoming less important in the fourth and fifth centuries, then a wholly new set of commemorations was beginning to command attention, this time clustered around Peter as the new founder of a new Christian (but still imperial) Rome.

\section{Bibliography}

Bagnall, R., A. Cameron, S. Schwartz, \& K. A. Worp. 1987. Consuls of the Later Roman Empire. Atlanta: Scholars Press.

Burgess, R. W. 2012. The Chronograph of 354: Its Manuscripts, Contents, and History. JLA 5.2: $345^{-96 .}$

55 On the visits, see Gillett (2001) 137-41.

56 Aug., Cum pagani ingrederentur 26: Venit imperator ... Posito diademate, pectus tundit ubi est piscatoris corpus; id. Enarr. in Ps. 65.4: Melius est ut Romam cum venerit imperator, deposito diademate, ploret ad memoriam piscatoris, quam ut piscator ploret ad memoriam imperatoris. For discussion of the historical and topographical contexts, see Fraschetti (1999) 261-3, and Liverani (2007).

57 Humphries (2012) 170.

$5^{8}$ See, most recently, McEvoy (2013), citing earlier bibliography.

59 Humphries (2012) 173-4; for an overview of the archaeology, see Jolivet \& Sotinel (2012). 
Cullhed, M. 1994. Conservator Urbis Suae: Studies in the politics and propaganda of the emperor Maxentius. Stockholm: Åströms.

Demacopoulos, G. E. 2013. The Invention of Peter: Apostolic Discourse and Papal Authority in Late Antiquity. Philadelphia: University of Pennsylvania Press.

Fraschetti, A. 1999. La Conversione: da Roma Pagana a Roma Cristiana. Bari: Laterza.

Gillett, A. 2001. Rome, Ravenna, and the Last Western Emperors. PBSR 69:131-67.

Gnilka, C. 2012. Römische Verfassungsgeschichte bei Prudentius und Ampelius. Hermes 140: $448-56$.

Gnilka, C. 2015. Kaiser, Rom und Reich bei Prudentius. In East and West in the Roman Empire of the Fourth Century: An End to Unity?, ed. R. Dijkstra, S. van Poppel, \& D. Slootjes, 164-79. Leiden: Brill.

Harries, J. 1984. Prudentius and Theodosius. Latomus 43: 69-84.

Hershkowitz, P. 2017. Prudentius, Spain, and Late Antique Christianity. Poetry, Visual Culture, and the Cult of Martyrs. Cambridge: Cambridge University Press.

Humphries, M. 2012. Valentinian III and the City of Rome (AD 425-55): Patronage, Politics, and Power. In Two Romes: Rome and Constantinople in Late Antiquity, ed. L. Grig \& G. Kelly, 161-82. New York: Oxford University Press.

Huskinson, J. M. 1982. Concordia Apostolorum: Christian Propaganda at Rome in the fourth and fifth centuries. A Study in early Christian Iconography and Iconology (BAR International Series 148). Oxford: British Archaeological Reports.

Jolivet, V., \& C. Sotinel. 2012. Die Domus Pinciana: Eine kaiserliche Residenz in Rom. In Rom und Mailand in der Spätantike: Repräsentationen städtischer Räume in Literatur, Architektur und Kunst, ed. T. Fuhrer, 137-6o. Berlin: De Gruyter.

Jordan, H. 1871. Topographie der Stadt Rom im Alterthum II. Berlin: Weidmann.

Liverani, P. 2007. Victors and Pilgrims in Late Antiquity and the Early Middle Ages. Fragmenta 1: 83-102.

Liverani, P. 2012. La cronologia della seconda basilica di S. Paolo fuori le mura. In Scavi e scoperte recenti nelle chiese di Roma, ed. H. Brandenburg \& F. Guidobaldi, 107-23. Vatican City: Pontificio istituto di archeologia cristiana.

Lønstrup Dal Santo, G. 2015. Concordia Apostolorum - Concordia Augustorum. Building a Corporate Image for the Theodosian Dynasty. In East and West in the Roman Empire of the Fourth Century: An End to Unity?, ed. R. Dijkstra, S. van Poppel, \& D. Slootjes, 99-120. Leiden: Brill.

McEvoy, M. 2013. The Mausoleum of Honorius. In Old StPeter's, Rome, ed. R. McKitterick, J. Osborne, C. M. Richardson, \& J. Story, 119-36. Cambridge: Cambridge University Press.

McLynn, N. 2008. Crying Wolf: The Pope and the Lupercalia. JRS 98: 161-75.

Momigliano, A. 1958. Some Observations on the 'Origo Gentis Romanae'.JRS 48: 56-73. Mommsen, T. ed. 1892. Chronica Minora I (MGH AA 9). Berlin: Weidmann. 
Mommsen, T. ed. 1893. Fasti Furii Dionysii Philocali et Polemii Silvii. CIL I²: 254-79.

O'Hogan, C. 2016. Prudentius and the Landscapes of Antiquity. Oxford University Press: Oxford.

Salzman, M. R. 1990. On Roman Time: the codex-calendar of 354 and the rhythms of urban life in late antiquity. Berkeley: University of California Press.

Smith, C. 2011. Thinking about Kings. BICS 54/2: 21-42.

Thacker, A. 2012. Patrons of Rome: the cult of Sts Peter and Paul at court and in the city in the fourth and fifth centuries. EME 20/4.380-406.

Thomson, H.J. 1949-1953. Prudentius. 2 vols. Harvard University Press: Cambridge, MA.

Trout, D. ed. 2015. Damasus of Rome: The Epigraphic Poetry. Oxford: Oxford University Press.

Van Nuffelen, P. 2012. Orosius and the Rhetoric of History. Oxford: Oxford University Press.

Wiseman, T. P. 1995. Remus: A Roman Myth. Cambridge: Cambridge University Press. 